\title{
АГРОЭКОЛОГИЧЕСКАЯ ОЦЕНКА СЕЛЬСКОХОЗЯЙСТВЕННОГО ЗЕМЛЕПОЛЬЗОВАНИЯ АЛТАЙСКОГО КРАЯ С ЦЕЛЬЮ УВЕЛИЧЕНИЯ ЕГО ПРОДУКТИВНОСТИ
}

\author{
S.N. Bocharov, V.L. Tatarintsev, L.M. Tatarintsev
}

\section{AGROECOLOGICAL EVALUATION OF AGRICULTURAL LAND USE OF ALTAI REGION IN ORDER TO INCREASE ITS PRODUCTIVITY}

Бочаров Сергей Николаевич - д-р экон. наук, проф., ректор Алтайского государственного университета, г. Барнаул. E-mail: kafzem@bk.ru

Татаринцев Владимир Леонидович - д-р с.-х. наук, проф., рук. стратегического проекта, профр. каф. экономической географиии и картографрии Алтайского государственного университета, г. Барнаул. E-mail: kafzem@bk.ru

Татариниев Леонид Михайлович - д-р биол. наук, проф. каф. землеустройства, земельного и городского кадастра Алтайского государственного аграрного университета, г. Барнаул.

E-mail: kafzem@bk.ru

Цель исследования - изучение земельноресурсного потенциала Алтайского края с применением агроэкологического анализа территории и определение экспортных возможностей сельскохозяйственного производства. Объектами научного исследования являются земли сельскохозяйственного назначения Алтайского края и процессы, тормозящие их полноценное использование. Базисом научного исследования стали постулаты факториальной экологии, нормативное обеспечение по разработке и проектированию адаптивноландшафотных земледельческих систем, а также методологические подходы по агроэкологической оценке земель. Основным методом научного исследования явился системный подход и его разновидность - эколого-экономический анализ. Потенциал земельных ресурсов Алтайского края велик. Даже при настоящем использовании территории (соотношение сельскохозяйственных угодий) увеличение продуктивности сельскохозяйственных земель сельскохозяйственными организациями края только по зерну пшеницы в стоимостном выражении (nри настоящих ценах) будет значительно превышать 30 млрд руб. Увеличение продуктивности
Bocharov Sergey Nikolaevich - Dr. Econ. Sci., Prof., Rector, Altai State University, Barnaul.

E-mail: kafzem@bk.ru

Tatarintsev Vladimir Leonidovich - Dr. Agr. Sci., Prof., Head, Strategic Projecting, Prof., Chair of Economic Geography and Cartography, Altai State University, Barnaul.

E-mail: kafzem@bk.ru

Tatarintsev Leonid Mikhaylovich - Dr. Biol. Sci., Prof., Chair of Land Management, Land and City Registry, Altai State University, Barnaul.

E-mail: kafzem@bk.ru

сельскохозяйственного землепользования $и$ получение большей прибыли с имеющейся площади возможно также посредством рассмотрения и моделирования направлений, связанных с изменением специализации сельскохозяйственных организаций с уклоном на животноводческую отрасль: организационно-правовыми вопросами организации сельскохозяйственного землепользования; переходом части сельскохозяйственных производителей на органическое сельское хозяйство. Современные земельные площади, относящиеся к сельскохозяйственным угодьям, полностью удовлетворяют потребностям внутреннего рынка, и по укрупненным расчетам, на основе агроэкологического анализа территории, экспортная продукция зерновых и зернобобовых культур в стоимостном выражении (при настоящих ценах) может значительно превышать 30 млрд руб. Такой вывод сделан на основании проведенной эколого-экономической оценки сельскохозяйственного землепользования. Учитывались природноклиматические условия региона, проявление водной эрозии и дефрляции, современный уровень агропромьшленного производства и другие фракторы. В результате проведенного на- 
учного исследования предложены различные модели сельскохозяйственного землепользования, направленные на его оптимизацию. Модели учитьвают экологическую, экономическую и социальную эффрективности при организации землепользования, используемого в агропромышленном производстве.

Ключевые слова: Алтайский край, агропромышленный комплекс, земли сельскохозяйственного назначения, агроэкологический анализ территории, продуктивность сельскохозяйственных угодий, сельскохозяйственная продукция.

The research objective was studying the land and resource capacity of Altai Region with application of agroecological analysis of the territory and the definition of export opportunities of agricultural production. The objects of scientific research were the soil of agricultural purpose of Altai Region and the processes which were slowing down their full use. The postulates of factorial ecology, standard providing on the development and design of adaptive and landscape agricultural systems, and also methodological approaches by agroecological assessment of lands became the basis of scientific research. The main method of scientific research was systematic approach and its ecological and economic analysis version. The potential of land resources of Altai Region is great. Even at real use of the territory (a ratio of agricultural grounds) the increase in the efficiency of farmlands by agricultural organizations of the region only for wheat grain in value terms (at the real prices) would exceed considerably 30 billion rubles. The increase in the efficiency of agricultural land use and receiving bigger profit from available area was possible also by means of consideration and modeling of the directions connected with changing of specialization of agricultural organizations with a bias on livestock branch: organizational and legal questions of the organization of agricultural land use; transition of part of agricultural producers to organic agriculture. Modern land areas relating to agricultural grounds completely meet the requirements of domestic market, and by integrated calculations, on the basis of agroecological analysis of the territory, export production of grain and leguminous crops in value terms (at the real prices) could exceed 30 billion rubles considerably. Such conclusion was drawn on the basis of carried-out ecological and economic assessment of agricultural land use. Climatic conditions of the region, manifestation of water erosion and deflation, modern level of agrarian and indus- trial production and other factors were considered. As a result of conducted scientific research various models of agricultural land use directed on its optimization were offered. The models consider ecological, economic and social efficiency at the organization of the land use used in agro-industrial production.

Keywords: Altai Region, agrarian and industrial complex, the lands of agricultural purpose, agroecological analysis of the territory, agricultural lands' efficiency, agricultural production.

Введение. Проанализировав динамику поставок алтайских товаров за пределы РФ в 2014-2018 гг., можно отметить, что в 2018 г. зафиксировано увеличение объема экспорта Алтайского края, составляющее 409,62 млн долл., или 55,68 \%, по сравнению с 2014 г. Наибольший объем поставок по итогам 2018 г. отмечен в марте и в денежном выражении составил 115,98 млн долл., при этом минимум пришелся на декабрь - 77,13 млн долл. [1, 2]. Среди товаров, поставляемых предприятиями Алтайского края, в пятерке самых востребованных нет продукции агропромышленного комплекса. Хотя по укрупненным расчетам валовая стоимость продукции только растениеводческого блока может составлять почти 40 млрд руб., при условии однородности зерна по качественным характеристикам. Поэтому возможность увеличения экспорта продукции АПК до уровня 500 млн долл. является вполне достижимой к 2024 г.

Цель исследования: изучение земельноресурсного потенциала Алтайского края с применением агроэкологического анализа территории и определение экспортных возможностей сельскохозяйственного производства.

Для достижения поставленной цели авторами решались задачи, связанные с агроэкологическим анализом сельскохозяйственного землепользования края и его последующей оптимизацией и интенсификацией использования.

Объекты и методы исследования. Объектами исследования являются земли сельскохозяйственного назначения Алтайского края и процессы, тормозящие их полноценное использование. Базисом научного исследования стали постулаты факториальной экологии, нормативное обеспечение по разработке и проектированию адаптивно-ландшафттных земледельческих систем, а также методологические подходы по агроэкологической оценке земель. Основным методом исследования явился системный под- 
ход и его разновидность - эколого-экономический анализ. Также для изучения локальных процессов и явлений использовались общераспространенные методы анализа и синтеза, сравнительный, статистический и монографиический.

Результаты исследования и их обсуждение. Ключевыми странами, покупающими продукцию из региона, в 2018 г. являются Казахстан (363,33 млн долл.), Украина (169,94 млн долл.), Китай (119,36 млн долл.), Узбекистан (66,46 млн долл.), Нидерланды (44,46 млн долл.). При этом первенствующая страна по экспортным поставкам Казахстан является лидером в структуре экспорта на протяжении всего периода.

Динамика средних экспортных цен в период 2014-2018 гг. оценивается как положительная, при этом рост составил 6,76 \%. На протяжении рассматриваемого периода среднеконтрактные цены экспорта Алтайского края колебались в пределах от 62,67 до 247,01 долл/т. Причем наибольшая средняя стоимость отмечена в июле 2015 г., а наименьшая - в январе 2016 г.
Как видно из приведенных выше данных по экспорту товаров из Алтайского края, продукция агропромышленного комплекса не входит в список наиболее востребованных за рубежом, хотя спрос на нее есть. Также следует отметить, что начиная с 2015 г. Алтайский край может напрямую взаимодействовать с зарубежными партнерами по поставкам сельскохозяйственной продукции.

Для изучения возможности увеличения объемов экспортируемой продукции следует проанализировать ресурсный потенциал территории края.

Площадь земель сельскохозяйственного назначения в Алтайском крае составляет более 11,5 млн га. Из них преобладающими угодьями является пашня - 6,5 млн га, на пастбища и сенокосы приходится соответственно боле 2,6 и 1,1 млн га [3].

Физико-географическое районирование Алтайского края представлено на рисунке 1 [4].

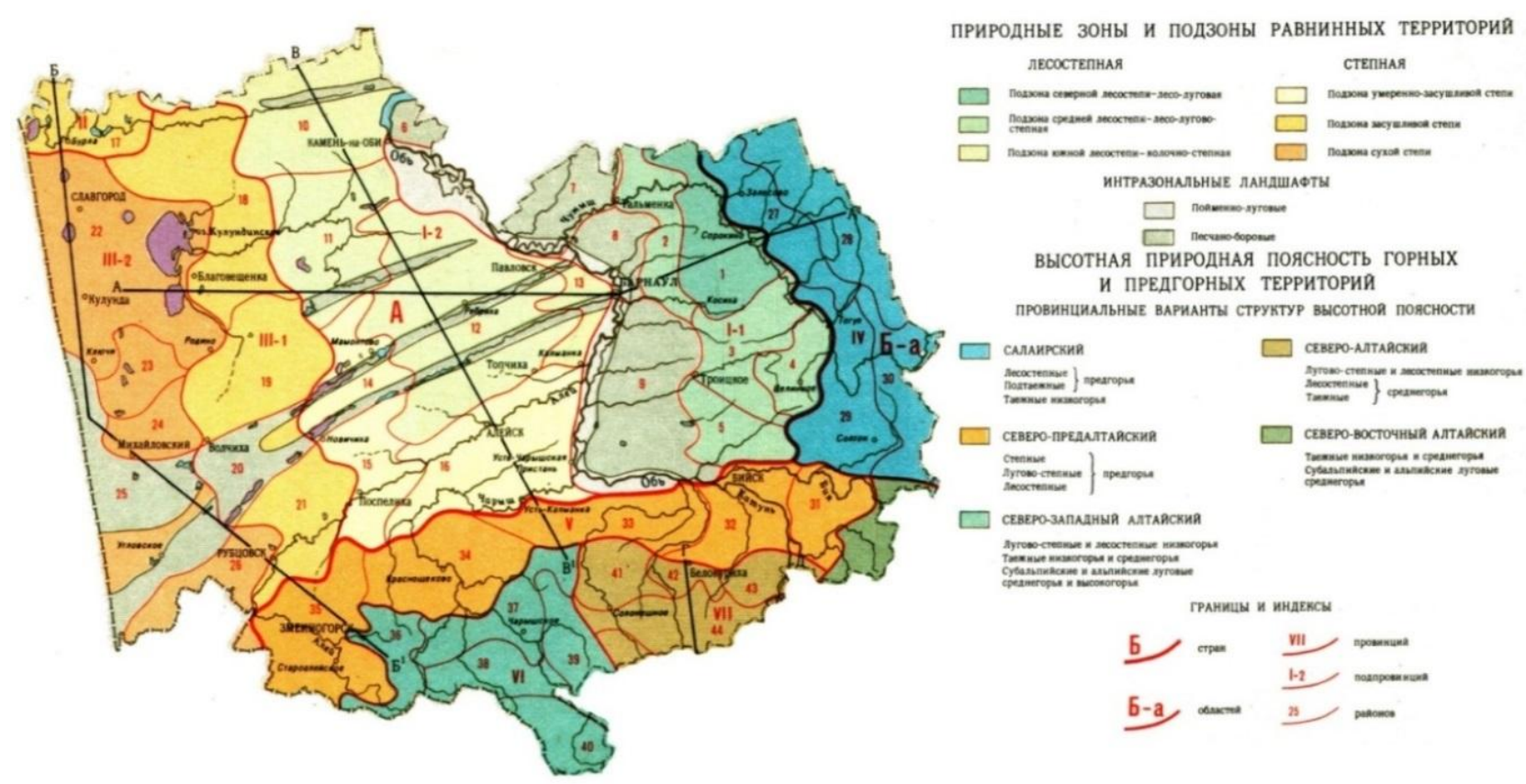

Puc. 1. Карта природных зон и подзон Алтайского края

Поэтому естественный продуктивный потенциал территории Алтайского края очень неоднородный.
Состав земель сельскохозяйственного назначения по подзонам представлен в таблице 1. 
Структура земель сельскохозяйственного назначения по подзонам края

\begin{tabular}{|c|c|c|c|c|c|c|c|}
\hline \multirow[b]{2}{*}{ Вид угодий } & \multicolumn{4}{|c|}{ Лесостепь } & \multicolumn{3}{|c|}{ Степь } \\
\hline & 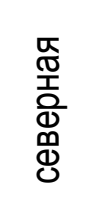 & 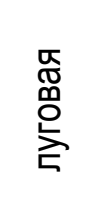 & $\begin{array}{l}\text { ㄸㅗㄸ } \\
\text { 좀 } \\
\text { ه } \\
\text { 잉 }\end{array}$ & 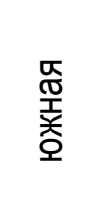 & 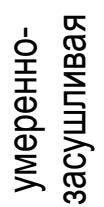 & 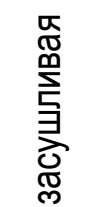 & $\begin{array}{l}\text { 荧 } \\
\text { 宓 }\end{array}$ \\
\hline Пашня & 45,6 & 50,8 & 64,5 & 60,2 & 61,5 & 62,4 & 65,3 \\
\hline Залежь & 4,8 & 2,8 & 0,2 & 0,6 & 1,4 & 2,6 & 4,7 \\
\hline Многолетние насаждения & 0,1 & - & 0,5 & 0,3 & 0,1 & 0,1 & - \\
\hline Сенокосы & 20,3 & 8,9 & 10,9 & 12,5 & 5,7 & 5,5 & 3,8 \\
\hline Пастбища & 21,3 & 27,0 & 17,1 & 17,5 & 23,6 & 21,8 & 18,7 \\
\hline Итого & 92,1 & 89,5 & 93,2 & 91,1 & 92,3 & 92,4 & 92,5 \\
\hline Прочие земли & 7,9 & 10,5 & 6,8 & 8,9 & 7,7 & 7,6 & 7,5 \\
\hline
\end{tabular}

Проанализировав данные таблицы 1, можно отметить, что абсолютно по всем природным зонам (подзонам) Алтайского края преобладающим сельскохозяйственным угодьем является пашня. Достаточно хорошо представлена потенциальная кормовая база (сенокосы и пастбища). Имеется резерв в виде залежных земель, и незначительные территории заняты многолетними насаждениями.

Урожайность зерновых и зернобобовых культур в Алтайском крае в период с 2014 по 2018 г. увеличилась с 0,9 до 15,7. Увеличение связано с благоприятными погодными условиями. Средняя урожайность зерновых и зернобобовых культур за последние пять лет составила 1,2 т/га.

Урожайность зерновых и зернобобовых культур за 2016 г. по муниципальным районам Алтайского края представлена на картосхеме рисунка 2 [5].

Из рисунка 2 видно, что большинство сельскохозяйственных организаций, находящихся в степной зоне Алтайского края, имеет очень низкую урожайность, редко превышающую 1,3 т/га. Только в двух муниципальных районах края средняя урожайность зерновых и зернобобовых культур находится на уровне 2,0 т/га и более.

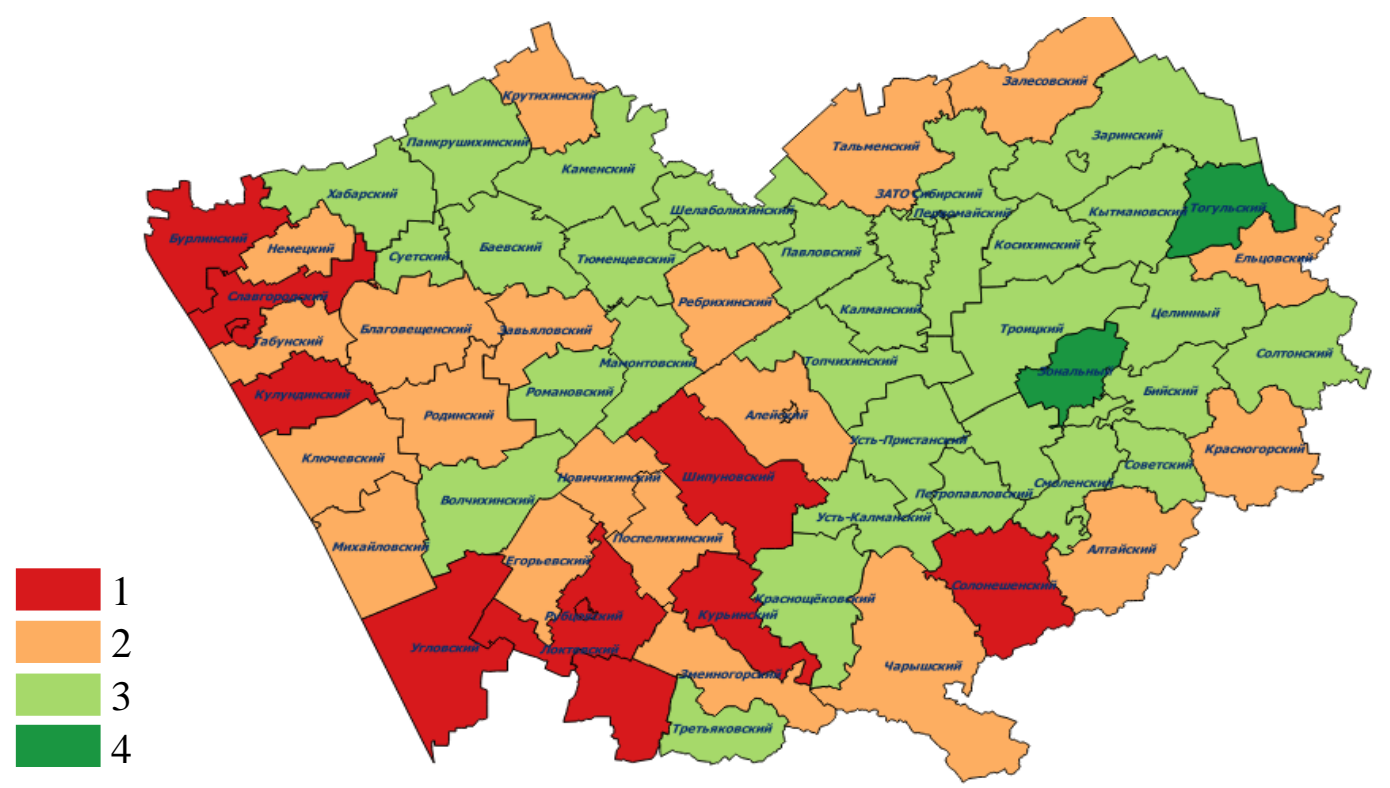

Puc. 2. Урожайность зерновых и зернобобовых культур по муниципальным районам Алтайского края (01.01.2017), m/2a (1 - <1; 2 - 1-1,3; 3 - 1,4-1,8; 4 - >1,9) 
Помимо естественной (природной) неоднородности территории, повышению эффеективности ее использования и оптимизации сельскохозяйственного производства препятствуют нега- тивные процессы: водная эрозия и дефрляция, а также их совместное проявление [6, 7].

Пространственное распределение доли эродированной пашни по муниципальным районам края представлено на картосхеме рисунка 3.

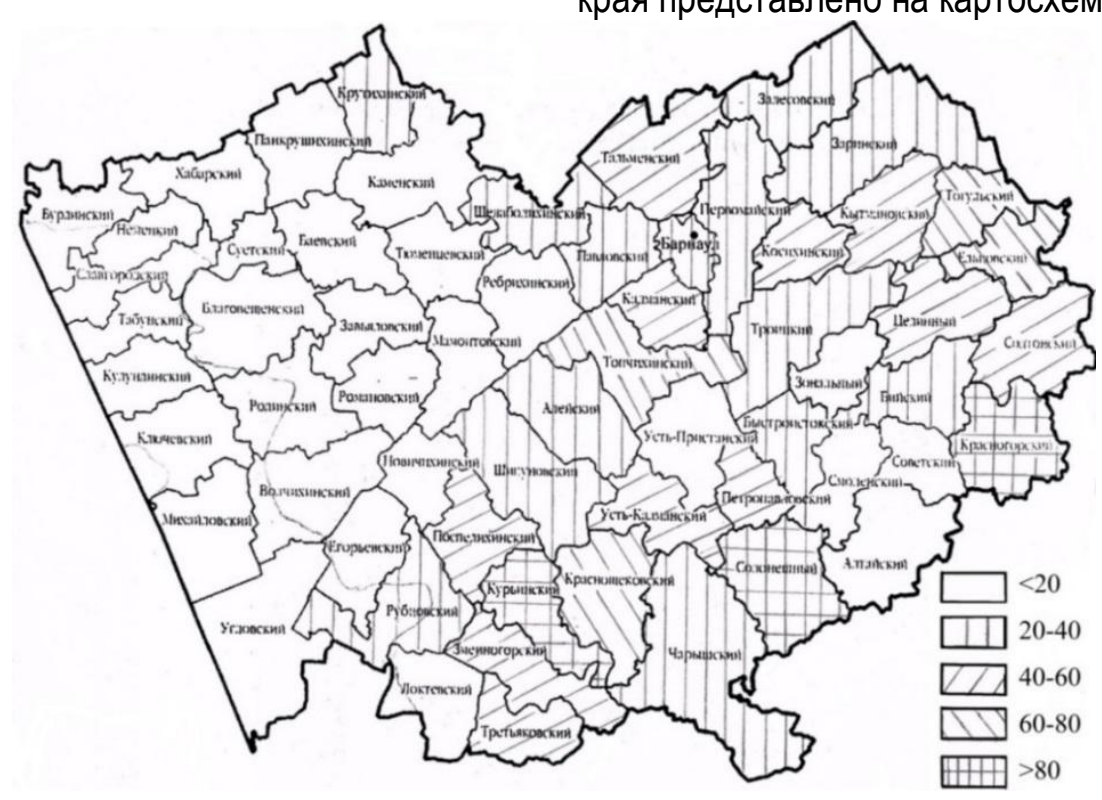

Puc. 3. Картосхема распространения доли пашни, подверженной эрозии по районам края

Очевидно, что в западном направлении растет дефляционная опасность земель сельскохозяйственного назначения и уменьшается эрозионная опасность. Соответствует этой тенденции и характер изменения доли эродированных и дефлированных сельхозугодий. Доля эродированной пашни по подзонам варьирует от 50 до почти 100 \% эрозионно опасной пашни. Эродированные кормовые угодья составляют соот- ветственно - от 40 до $100 \%$ и 25-80 \% площади, а вот дефолированные земли в северной лесостепи не выделяются. В остальных природноклиматических подзонах на дефрлированные пашню, сенокос и пастбища приходится 15$100 \%$ площади дефрляционно опасных угодий [8].

На рисунке 4 графически показано распространение по муниципальным районам края доли дефлированной пашни.

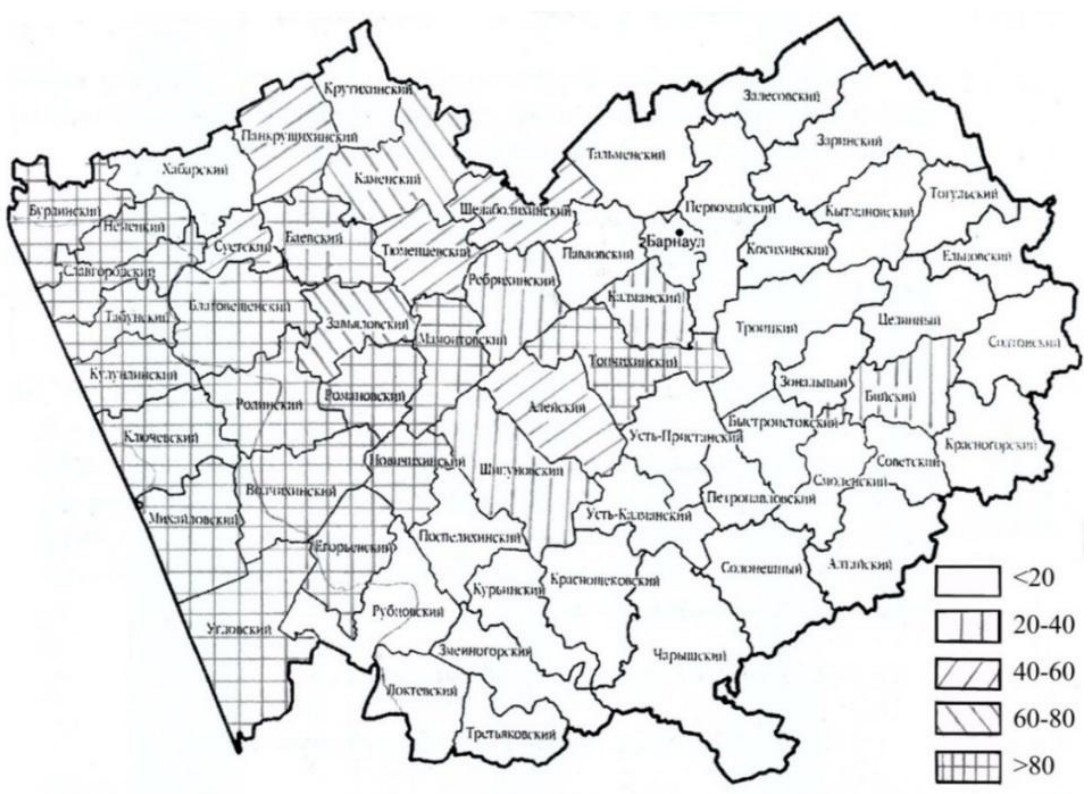

Puc. 4. Картосхема распространения доли дефолированной пашни по районам края 
Из картосхемы рисунка 4 видно, что среди эродированных и десрлированных угодий (пашня, сенокос, пастбище) доминируют слабоэродированные и слабодефрлированные, на среднеэродированные приходится до одной трети эродированной площади. Пашня средней степени десрлированности достигает $21 \%$, кормовых угодий - почти $40 \%$. Сильнодефрлированная пашня не отмечена, сильнодефлированные сенокосы встречаются только в сухой степи, а пастбища - в южной лесостепи.

Основной территорией Алтайского края, где производится абсолютная доля растениеводческой продукции (зерно яровой пшеницы), является зона степи. Здесь почти повсеместно проявляется ветровая эрозия (десрляция). На дефрлированных угодьях происходит значительное снижение урожайности зерна яровой пшеницы. Так, средняя урожайность зерновых на пашне с отсутствием дефрляционных процессов составляет 1,2 т/га; на слабодефрлированных землях 0,9; среднедефллированных - 0,7; на сильнодефлированных - 0,5 т/га. Если принять в расчетах цену реализации 1 т зерна 10 тыс. руб., а общие затраты 8 тыс. руб/га, то себестоимость 1 т изменится с 6,7 тыс. руб. на недефлированной пашне до 16 тыс. руб. на сильнодефлированной, прибыль/убыток будет составлять 3,3 тыс. руб. и 6,0 тыс. руб. соответственно. Рентабельность производства зерна в первом случае будет составлять 50 \%, а на сильнодефлированных и среднедефлированных производство будет нерентабельным.

Если принять в расчет значения цены реализации зерна яровой пшеницы 3-го класса, производственных затрат на 1 га, себестоимости 1 т зерна и прибыли, то в степной зоне экономические потери от дефляционных процессов составят даже при учете слабой степени эолового процесса (дефляции), в натуральных единицах - 840 тыс. т; в стоимостных - 8,4 млрд руб.; при стоимости реализации зерна - 10 тыс. руб. за 1 т. Если произвести расчеты прибыльности производства на средне- и сильнодефлированной пашне, то затраты будут перекрывать доходы от производства.
Чтобы получить 1 т яровой пшеницы, требуется от 0,77-1,05 га пашни. Для производства (в живом весе) 1 т мяса используются 13 га сельхозугодий в средней лесостепи и 22,5 га в сухой степи. Тонна молока соответствует 1,83,3 га кормовых угодий, а на содержание одной условной головы КРС необходимо 3,4 до 5,8 га сенокосов и пастбищ. При настоящем уровне производства каждый миллион рублей, заработанный в АПК в лесостепной зоне, связан в среднем с 220 га сельскохозяйственных угодий, в степной - площадь увеличивается на 26 га [9-11]. Показатель землеемкости в лесостепи в растениеводстве составляет 214 га, а в животноводстве - 212 га. При производстве растениеводческой продукции в степи землеемкость возрастает по сравнению с лесостепью на 30 га, а в животноводстве - на 13 га. Повышение землеемкости связано со снижением продуктивности основных сельскохозяйственных угодий.

В соответствии с Концепцией рационального использования земель сельскохозяйственного назначения Алтайского края в современных условиях на каждого жителя края при нынешней продуктивности сельскохозяйственных угодий должно приходиться 1,03 га пашни и 1,14 га кормовых угодий, т. е. достаточно 2,6 млн га пашни [12]. Остальная пашня может быть использована для выращивания продукции на экспорт, а также в средостабилизирующих целях $[13,14]$ (табл. 2).

Согласно принципам достаточности, экологических требований и экономических возможностей, решение задачи увеличения экспорта сельскохозяйственной продукции можно рассмотреть посредством разработки условных моделей землепользования и оптимизации агроландшафтов с учетом влияния на него внешних и внутренних факторов [15]. Безусловно, в моделях будут учитываться экологическая, экономическая и социальная эффективность, а доля природоохранных компонентов будет изменяться с 2 до почти 80 \% площади, что скажется на конечном результате использования территории. 
Проектируемое использование пашни по подзонам Алтайского края, тыс. га

\begin{tabular}{|c|c|c|c|c|c|c|}
\hline 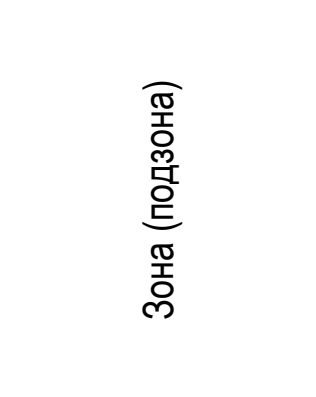 & 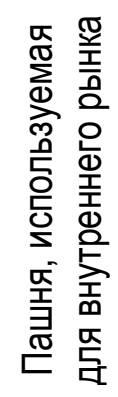 & 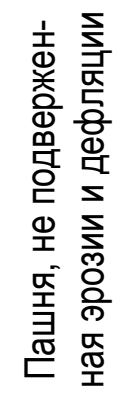 & 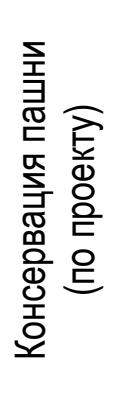 & 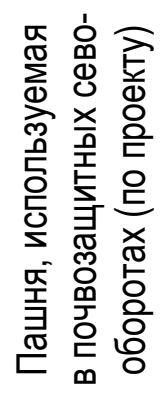 & 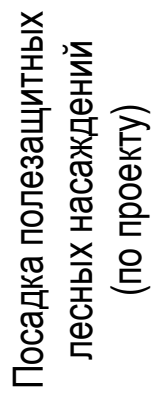 & 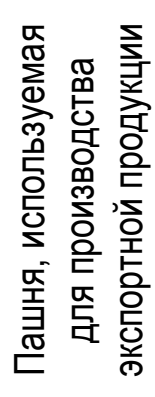 \\
\hline $\begin{array}{l}\text { Северная } \\
\text { лесостепь }\end{array}$ & 220,0 & 217,2 & 43,0 & 187,0 & 7,6 & 219,5 \\
\hline Луговая лесостепь & 265,0 & 392,4 & 77,7 & 341,8 & 5,6 & 481,2 \\
\hline $\begin{array}{l}\text { Средняя } \\
\text { лесостепь }\end{array}$ & 560,0 & 646,6 & 26,2 & 242,7 & 15,6 & 339,9 \\
\hline $\begin{array}{l}\text { Южная лесостепь } \\
\text { (колочная степь) }\end{array}$ & 398,0 & 284,9 & 44,0 & 642,6 & 16,1 & 557,3 \\
\hline $\begin{array}{l}\text { Умеренно- } \\
\text { засушливая степь }\end{array}$ & 423,0 & 57,1 & 280,1 & 860,9 & 15,6 & 759,6 \\
\hline Засушливая степь & 420,0 & 383,9 & 105,1 & 710,0 & 15,0 & 794,1 \\
\hline Сухая степь & 270,0 & 11,7 & 84,0 & 770,7 & 9,7 & 586,7 \\
\hline Итого & 2556 & 1993,8 & 660,1 & 3755,7 & 95,2 & 3738,3 \\
\hline
\end{tabular}

Первая модель (высокоресурсозатратная) - землепользование осуществляется по сложившейся структуре сельскохозяйственных угодий в настоящее время. Данная схема использования земель может быть усилена внесением органических и минеральных удобрений. Органические удобрения вносятся по локальным площадям пашни, которая обеспечена развитым животноводством. Минеральные удобрения вносятся на территории края в дозах менее 10 кг/га. Однако, по нашим расчетам, даже при таком землепользовании возможно увеличение экспорта зерна как минимум в два раза.

Вторая модель (среднересурсозатратная) - средне- и сильнодефлированные пахотные угодья становятся залежью, а сильнодефлированные кормовые угодья занимаются лесопосадками средостабилизирующего значения.

При реализации низкоресурсозатратной модели залежь преобразуется в улучшенный сенокос, а низкопродуктивная пашня переводится в залежь.

В равновесной модели пашня, луг и лес в процентном отношении занимают примерно одинаковую площадь (около 30 \%).
Модель, ориентированную на обеспечение внутреннего потребления в регионе сообразно медицинским нормам, условно назовем медицински обоснованной. Остальная пашня переводится в залежные земли, предназначенные для воспроизводства почвенного плодородия и стабилизации землепользования.

Модель, которая и вовсе не предполагает в своем составе такого сельскохозяйственного угодья, как пашня, и основывается на активном использовании кормовых угодий, может быть условно названа целинной. Она предполагает изменение специализации региона на молочномясное животноводство.

Можно также спроектировать лесохозяйственно-природоохранную, переложную, почвозащитную модели, которые направлены на сохранение и преумножение почвенного плодородия территории, оптимизацию сельскохозяйственного землепользования. Все модели, кроме первой, требуют значительного лага времени и капитальных вложений, срок окупаемости которых более 10 лет [16].

Заключение. Резюмируя вышеизложенное, следует отметить, что потенциал земельных 
ресурсов Алтайского края велик. Даже при настоящем использовании территории (соотношение сельскохозяйственных угодий) увеличение продуктивности сельскохозяйственных земель сельскохозяйственными организациями края только по зерну пшеницы в стоимостном выражении (при настоящих ценах) будет значительно превышать 30 млрд руб.

Увеличение продуктивности сельскохозяйственного землепользования и получение большей прибыли с имеющейся площади, по нашему мнению, возможно также посредством рассмотрения и моделирования следующих направлений, связанных с изменением специализации сельскохозяйственных организаций с уклоном на животноводческую отрасль: организационно-правовыми вопросами организации сельскохозяйственного землепользования; переходом части сельскохозяйственных производителей на органическое сельское хозяйство.

\section{Литература}

1. URL: https://tebiz.ru/mi/eksport-altajskogokraya?_openstat=ZGlyZWN0 LnlhbmRleC5yd TsyMzM1Mj U1OTszMzQ4 MDAyOTc4O2dv Lm1 haW wucnU6cHJlbWl1bQ\&yclid=451321 2391846349154.

2. URL: https://obzor.city/news/34891.

3. Бунин А.А., Репенек Д.А., Татаринцев В.Л., Татаринцев Л.М. Анализ структуры земель сельскохозяйственного назначения Алтайского края // Вестн. Алтайского гос. аграр. ун-та. - 2018. - № 3 (161). - С. 19-26.

4. Атлас. Алтайский край. Т. 1. - М.; Барнаул, 1978. - 222 c.

5. Халин Н.С., Назарова И.В., Симакова С.А., Дьмова Л.В. и др. Мониторинг плодородия почв земель сельскохозяйственного назначения Алтайского края: справочник. - Барнаул: Параграфр, 2019. - 384 с.

6. Орлов А.Д. Эрозия и эрозионные земли Западной Сибири. - Новосибирск, 1983. 208 c.

7. Каштанов А.Н. Защита почв от ветровой и водной эрозии. - М.: Россельхозиздат, 1974. - 208 c.

8. Бунин А.А., Зырянов А.А., Мягкий П.А., Татаринцев В.Л. и др. Зональные и внутризональные особенности развития эрозии и десляции в Алтайском крае // Вестн. Алтайского гос. аграр. ун-та. - 2017. № 2 (148). - C. 29-37.

9. Татаринцев Л.М., Татаринцев В.Л., Будрицкая И.А., Латышева О.А. Концепция управления земельными ресурсами Алтайского края в современных условиях // Вестн. Алтайского гос. аграр. ун-та. 2014. - № 1 (111). - C. 137-142.

10. Латьшева О.А., Татаринцев В.Л., Татаринцев Л.М., Бунин А.А. Повышение эффективности сельскохозяйственного землепользования в Алтайском крае // Вестн. Алтайского гос. аграр. ун-та. - 2017. № 5 (151). - C. 35-43.

11. Татаринцев Л.М., Татаринцев В.Л., Бунин А.А. Пути повышения эфффективности использования земель сельскохозяйственного назначения в Алтайском крае // Геодезия, землеустройство и кадастр: вчера, сегодня, завтра: сб. мат-лов междунар. науч.-практ. конф., посвящ. 95-летию землеустроительного факультета Омского ГАУ. - Омск: Изд-во Омского ГАУ, 2017. - С. 172-177.

12. Концепция рационального использования земель сельскохозяйственного назначения Алтайского края в современных условиях // Производство продукции сельского хозяйства в Алтайском крае в современных условиях: проблемы и решения: мат-лы региОн. науч.-практ. конф. (4-5 марта 1998 г., Барнаул). - Барнаул, 1998. - С. 370-424.

13. Кирюшин В.И. Концепция адаптивноландшафтного земледелия. - Пущино, 1993. - 236 c.

14. Кирюшин В.И. Экологизация земледелия и технологическая политика. - М.: Изд-во MCXA, 2000. - 473 c.

15. Татаринцев Л.М., Татаринцев В.Л., Латью шева О.А., Никулин А.А. Агроэкологическое зонирование территории сухой степи Алтайского края // Вестн. Алтайского гос. аграр. ун-та. - 2016. - № 4 (138). - С. 76-82.

16. Татаринцев Л.М., Татаринцев В.Л., Власова Т.В. Моделирование современного землепользования в сухой степи. - Барнаул: Изд-во АГАУ, 2010. - 103 с. 


\section{Literatura}

1. URL: https://tebiz.ru/mi/eksport-altajskogokraya?_openstat=ZGlyZWNO LnlhbmRleC5yd TsyMzM1Mj U10TszMzQ4 MDAyOTc40 2dvLm1haW wu-cnU6cHJlbWl1bQ\&yclid= 4513212391846349154.

2. URL: https://obzor.city/news/34891.

3. Bunin A.A., Repenek D.A., Tatarincev V.L., Tatarincev L.M. Analiz struktury zemel' sel'skohozyajstvennogo naznacheniya Altajskogo kraya // Vestn. Altajskogo gos. agrar. un-ta. - 2018. - № 3 (161). - S. 19-26.

4. Atlas. Altajskij kraj. T. 1. - M.; Barnaul, 1978. $222 \mathrm{~s}$.

5. Halin N.S., Nazarova I.V., Simakova S.A., Dymova L.V. i dr. Monitoring plodorodiya pochv zemel' sel'skohozyajstvennogo naznacheniya Altajskogo kraya: spravochnik. - Barnaul: Paragraf, 2019. - $384 \mathrm{~s}$.

6. Orlov A.D. Eroziya i erozionnye zemli Zapadnoj Sibiri. - Novosibirsk, 1983. - 208 s.

7. Kashtanov A.N. Zashchita pochv ot vetrovoj i vodnoj erozii. - M.: Rossel'hozizdat, 1974. $208 \mathrm{~s}$

8. Bunin A.A., Zyryanov A.A., Myagkij P.A., Tatarincev V.L. i dr. Zonal'-nye i vnutrizonal'nye osobennosti razvitiya erozii i deflyacii v Altajskom krae // Vestn. Altajskogo gos. agrar. un-ta. - 2017. - № 2 (148). S. 29-37.

9. Tatarincev L.M., Tatarincev V.L., Budrickaya I.A., Latysheva O.A. Koncepciya upravleniya zemel'nymi resursami Altajskogo kraya v sovremennyh usloviyah // Vestn. Altajskogo gos. agrar. un-ta. - 2014. - № 1 (111). S. 137-142.
10. Latysheva O.A., Tatarincev V.L., Tatarincev L.M., Bunin A.A. Povyshenie effektivnosti sel'skohozyajstvennogo zemlepol'zovaniya $\mathrm{v}$ Altajskom krae // Vestn. Altajskogo gos. agrar. un-ta. - 2017. - № 5 (151). - S. 35-43.

11. Tatarincev L.M., Tatarincev V.L., Bunin A.A. Puti povysheniya effektivnosti ispol'zovaniya zemel' sel'skohozyajstvennogo naznacheniya v Altajskom krae // Geodeziya, zemleustrojstvo i kadastr: vchera, segodnya, zavtra: sb. matlov mezhdunar. nauch.-prakt. konf., posvyashch. 95-letiyu zemleustroitel'nogo fakul'teta Omskogo GAU. - Omsk: Izd-vo Omskogo GAU, 2017. - S. 172-177.

12. Koncepciya racional'nogo ispol'zovaniya zemel' sel'skohozyajstvennogo naznacheniya Altajskogo kraya v sovremennyh usloviyah // Proizvodstvo produkcii sel'skogo hozyajstva $v$ Altajskom krae $\mathrm{v}$ sovremennyh usloviyah: problemy i resheniya: mat-ly region. nauch.prakt. konf. (4-5 marta 1998 g., Barnaul). Barnaul, 1998. - S. 370-424.

13. Kiryushin V.I. Koncepciya adaptivnolandshaftnogo zemledeliya. - Pushchino, 1993. - $236 \mathrm{~s}$.

14. Kiryushin V.I. Ekologizaciya zemledeliya i tekhnologicheskaya politika. - M.: Izd-vo MSKHA, 2000. - $473 \mathrm{~s}$.

15. Tatarincev L.M., Tatarincev V.L., Latysheva O.A., Nikulin A.A. Agroekologicheskoe zonirovanie territorii suhoj stepi Altajskogo kraya // Vestn.Altajskogo gos. agrar. un-ta. - 2016. № 4 (138). - S. 76-82.

16. Tatarincev L.M., Tatarincev V.L., Vlasova T.V. Modelirovanie sovremennogo zemlepol'zovaniya $v$ suhoj stepi. - Barnaul: Izd-vo AGAU, 2010. - $103 \mathrm{~s}$. 